\title{
Correction to: Embodied memories: Reviewing the role of the body in memory processes
}

\section{Francesco lanì $^{1}$}

Published online: 16 March 2020

(C) The Psychonomic Society, Inc. 2020

Correction to: Psychonomic Bulletin \& Review(2019) 26:1747-1766

https://doi.org/10.3758/s13423-019-01674-x

This paper omitted a reference:

Dutriaux, L., \& Gyselinck, V. (2016). Learning is better with the hands free: The role of posture in the memory of manipulable objects. PLOS ONE, 11(7), e0159108. https://doi.org/ 10.1371/journal.pone.0159108

Publisher's note Springer Nature remains neutral with regard to jurisdictional claims in published maps and institutional affiliations.

The online version of the original article can be found at https://doi.org/ 10.3758/s13423-019-01674-x

Francesco Ianì

francesco.iani@unito.it

1 Dipartimento di Psicologia, Università di Torino, Via Po, 14,

10123 Turin, Italy 